\title{
メチシリン耐性黄色ブドウ球菌を主とした 院内感染防止対策に関する提言
}

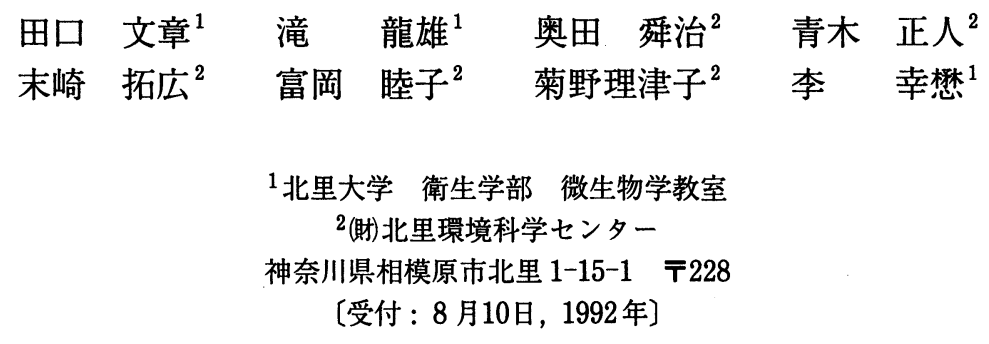

メチシリン耐性黄色ブドウ球菌（MRSA）による院内環境の污染状況を把握する目的で, 患者の寝具を中心にMRSA の分布を定量的に調査した。その結果, 次のような成績を得た。 1. 11 病院の使用中の患者用マットレス 52 枚を調査し, 10 施設のマットレスの $25 \sim 100 \%$ から，最高 $>6 \times 10^{4}$ 集落 (CFU) $/ 100 \mathrm{~cm}^{2}$ の MRSA が検出された。

2. 患者用のシーツとマットレス, および病室, 洗濯室, 浴室の脱衣室, トイレと污物室な どの床から最高 $>6 \times 10^{4} \mathrm{CFU} / 100 \mathrm{~cm}^{2}$ の MRSA とメチシリン耐性コアグラーゼ陰性ブド ウ球菌（MRCNS）が分離された。

3. 患者 20 名の手のひらを検査して 7 名から MRCNS が, 8 名から MRSA が検出され，ま た医療従事者（医師, 看護婦を含む）16名の手のひらは 6 名が MRCNS 陽性であったが MRSA は検出されなかった。

これらの結果は, マットレスや病室の床など院内環境が, MRSA や MRCNSに濃厚に污 染されていること, 並びにマットレスなどの洗濯と消毒の必要なことを示唆するものと考え られる。

臓器移植, 腫瘍および免疫抑制剤の投与などで 免疫能が低下している患者に日和見感染症と, ま た別に多剂耐性菌による難治性感染症および院内 感染症が増加している7,9,17)。院内環境に存在す る細菌に関する実態調查は, 院内感染発生との因 果関係の意味付けが多くの場合困難であり；また 検出された細菌数が環境基準值として許容できる か否かを判断することも難しいと言われている2,3, 5)。

一方, 手術室等の高度に清潔度が要求される場 所については,すでに多くの細菌学的な調査研究 が行われている10,11,13,16)。しかし, 現在社会的に
問題視されているメチシリン耐性黄色ブドウ球菌 (MRSA) については, 臨床材料からの分離状況 （菌株数や分離率）に関する報告は多数あるが8,12, 14), 病院の一般環境におけるMRSAの分布や特 にその生存菌数の定量值に関する報告はいまだほ とんどない1)。

MRSA の様な特定菌に関する病院内環境の実 態を把握することは, これらの菌による院内感染 防止対策を検討する際の不可欠な基礎資料である と考えられる。われわれは，MRSAの選択的分 離培地を開発し，この培地を使用することにより MRSA を定量できることを先に報告した15)。そ 
こで, MRSAによる院内污染の伝播源として, 病 室内の寝具が大きな要因ではないかとの仮説のも とに, 何年間も使用されていても洗濯や消毒の対 象にされにくい患者用マットレスを検査対象の中 心にMRSAに関する定量試験を試みた。その結 果, 調査した病院の $90 \%$ で現在使用している患 者用マットレスが MRSA で污染されている成績 を得た。これらの調査結果と合わせて, 院内環境 の MRSA モニタリング法についての提言を，以 下に報告する。

\section{材料と方法}

\section{調查対象施設}

関東・東北地区の 11 施設の協力を得て, 患者 用マットレス等の細菌学的調査を実施した。定量 的な院内環境の実態調查は, 検体採取から細菌分 離試験実施までの時間的要因を考慮して行程が一 日範囲内の，おもに A 病院 (総合病院, 約170床), $\mathrm{B}$ 病院（総合病院，約 170 床), $\mathrm{C}$ 病院（総合病院, 約 220 床), D 病院 (大学病院, 約 1,000 床), と $\mathrm{E}$ 病院 (老人病院, 約 130 床)の 5 施設であった。こ れらの11施設は，マットレス等を含む院内環境 の MRSA の実態調査の経験のない施設であった。

\section{細菌検査対象物}

病室を含む検査の場所は, 各医療施設の希望 と指示にしたがい, 無作為的に抽出した。寝具類 およびベッドについては, マットレス, マットレ スパット，シーツおよびベッドの手すりを検査対 象とした。

病院の一般環境については, 病室床, 空調機給 気口，ブラインド，掃除用モップ，スリッパ，ま た洗濯室, 浴室, トイレ, 洗濯物の保管に使う污 物室等の床などを検査対象とした。

人については, 唯一許可の得られた $\mathrm{E}$ 病院の患 者と医療従事者（医師，看護婦，補助者）の鼻腔 (鼻前庭), 咽頭, 手のひらを対象とした。対照と しての健康者は, ボランティアの大学生の鼻腔を 調べた。

\section{検体の採取方法}

物体からの検体採取は, おもに次の 3 種類の方 法を用いた。

1. 拭き取り法: $2 \mathrm{ml}$ の生理食塩液を浸した 滅菌拭き取りプース（成型ガーゼ: 澤田棉行）で 検体採取䇢所（測定できる所は $10 \mathrm{~cm} \times 10 \mathrm{~cm}$ の
面積を, 表面が $100 \mathrm{~cm}^{2}$ 以下の所は面積を実測し た）を強固な大型ピンセットを用いて強く拭き取っ た。プース付着菌を $20 \mathrm{~m} l$ の生理食塩液中で振り 出し (約 $30 \mathrm{~cm}$ の振幅で 30 回強く振る), その振 り出し液を試料原液とした。

2. 掃除機法: マットレス表面に電気掃除機を かけ，ごみを採取した。採取したごみは無菌のビ ニール袋にいれて検査用試料とした。試料全体の 重量を測定し, 生理食塩液で $0.25 \sim 1.25 \mathrm{w} / \mathrm{v} \%$ の 浮遊液を調製し，これを試料原液とした。掃除機 は，家庭用のものを試料採取専用機として用い， 吸引筒の中にごみ採取用の袋（パックフィルター を吸引筒の径に合わせて袋状にしたもの）をとり つけた。採取の都度吸引口は消毒用アルコールで 消毒し乾燥させた。

3.スタンプ法: 一般細菌検出用には表面積が $10 \mathrm{~cm}^{2}$ のフードスタンプ生菌数用・標準寒天（日 水製薬), 黄色ブドウ球菌検出用にはフードス夕 ンプ黄色ブドウ球菌用・TGSE 寒天（日水製薬） をマットレス表面に強めに付着させ直接菌を採取 した。人からの検体採取は, 鼻腔 (鼻前庭) と咽 頭については, 滅菌綿棒で常法にしたがって拭き 取った。手のひらは, 環境拭き取り用の滅菌プー スで強く拭き取った。

なお， 1 対象物（モップとスリッパを除く）に つき 3 力所から検体を採取した。

\section{細菌検查の方法}

1. 拭き取り法および掃除機法の試料原液か らの検査

一般生菌数の測定および同定: 生理食塩液で試 料原液の 10 倍希釈列を調製し，そのそれぞれか ら $1 \mathrm{ml}$ ずつ 2 枚のシャーレに取り,トリプチケー スソイ寒天培地（日水製薬）で混釈平板とし $37 \mathrm{C}$, 48 時間培養後の集落を算定した。優占菌は, 必要 に応じて Cowanの第一次鑑別により大まかな分 類を行いアピシステム（アスカ純薬）および ID テスト（日水製薬）等の同定キットを用いて種ま での同定を行った。

黄色ブドウ球菌数: 試料原液の $5 \mathrm{ml}$ を所定の 2 倍濃度の $7.5 \% \mathrm{NaCl}$ 加トリプチケースソイブ ロス $5 \mathrm{ml}$ と混合して $37 \mathrm{C}, 24$ 時間増菌培養後, MRSA 分離培地 ${ }^{15}$ ) (多剂耐性ブドウ球菌の選択 分離培地として考案したもの，極東製薬）および マンニット食塩卵黄（MSEY，日水製薬）培地で 
分離培養した。同時に MRSA 分離培地および MSEY 培地に試料希釈液の $0.1 \mathrm{ml}$ ずつを培地表 面にコンラージ棒で叙布し $37 \mathrm{C} ， 48$ 時間培養して 卵黄反応陽性集落を算定した。さらにこれらの集 落群から代表的な集落を釣菌し，ウサギプラズマ (栄研化学) を用いコアグラーゼ反応を実施した。 $\mathrm{E}$ 病院の院内環境および患者と医療従事者から分 離した菌については, 代表的集落を釣菌し, 同定 キットを用い, 種までの同定を行った。なお，コ アグラーゼ反応陽性のものについては, ブドウ球 菌コアグラーゼ型別用試薬（デンカ生研）を用い コアグラーゼの型別を行った。さらに，同定菌に ついてはすべて MRSA スクリーン培地（BBL） で発育の有無を確認した。

\section{2. スタンプ法の検査}

採取したスタンプアガーを $37 \mathrm{C} て ゙ ~ 48$ 時間培養 し, フードスタンプ標準寒天培地上の集落を数え, $10 \mathrm{~cm}^{2}$ 当たりの一般生菌数とした。フードスタン プ TGSE 寒天培地も同様に培養し, 黒色で集落周 辺が白濁した集落を黄色ブドウ球菌として数えた。

3. 人の鼻前庭と咽頭から採取した試料の検査
綿棒は, MRSA 分離培地および MSEY 培地に

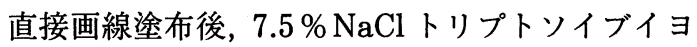
ンに接種し増菌培養した。増菌培養については, さらに直接分離培地と同じ培地に分離培養した。 直接分離培養, 増菌培養ともに $37 \mathrm{C}$ で 48 時間培 養した。代表的ブドウ球菌様集落を卵黄反応陽性・ 陰性それぞれについて釣菌し拭き取り法と同手順 でブドウ球菌の同定およびコアグラーゼの型別検 查を行った。人の手のひらから採取した滅菌プー スは拭き取り法と同一手順で検査を行った。

\section{成 績}

\section{試料採取方法の検討}

マットレスのような表面が凸凹のある物に付着 している細菌の定量的な調査をする場合, どのよ うな試料の採取が適切かを知るために，拭き取り 法，スタンプ法と掃除機法の 3 方法で採取したサ ンプルを用い, 検出される一般細菌の生菌数を調 べた。検査病室は, 概ね同規模の総合病院 $\mathrm{A}, \mathrm{B}$, $\mathrm{C}$ の一般患者用 $4 \sim 6$ 人用の病室で, 入口に近い 患者のベッドを検査した。結果は，1対象物につ

表 1. マットレス表面の一般細菌数

\begin{tabular}{|c|c|c|c|c|}
\hline 施 設 & ベッド番号 & 拭き取り法 & 掃 除 機 法 & スタンプ法* \\
\hline \multirow{6}{*}{$\begin{array}{l}\text { A } \\
\text { 病 } \\
\text { 院 }\end{array}$} & 1 & $2.6 \times 10^{2}$ & $3.5 \times 10^{2}$ & $3.5 \times 10^{2}$ \\
\hline & 2 & $3.0 \times 10^{5}$ & $4.8 \times 10^{4}$ & $6.3 \times 10$ \\
\hline & 3 & $2.8 \times 10^{5}$ & $3.4 \times 10^{2}$ & $3.8 \times 10^{2}$ \\
\hline & 4 & $3.0 \times 10^{5}$ & $8.1 \times 10^{3}$ & $6.5 \times 10$ \\
\hline & 5 & $8.8 \times 10^{5}$ & $1.3 \times 10^{3}$ & $2.4 \times 10^{2}$ \\
\hline & 平 均 & $3.5 \times 10^{5}$ & $1.1 \times 10^{4}$ & $2.2 \times 10$ \\
\hline \multirow{6}{*}{$\begin{array}{l}\text { B } \\
\text { 病 } \\
\text { 院 }\end{array}$} & 1 & $3.0 \times 10^{5}$ & $1.2 \times 10^{3}$ & $5.8 \times 10$ \\
\hline & 2 & $3.0 \times 10^{5}$ & $4.1 \times 10^{3}$ & $8.2 \times 10$ \\
\hline & 3 & $1.3 \times 10^{3}$ & $1.6 \times 10^{3}$ & $3.6 \times 10^{2}$ \\
\hline & 4 & $1.3 \times 10^{5}$ & $1.3 \times 10^{4}$ & $7.0 \times 10$ \\
\hline & 平 均 & $1.8 \times 10^{5}$ & $5.0 \times 10^{3}$ & $1.4 \times 10^{2}$ \\
\hline & 1 & $1.3 \times 10^{4}$ & $5.6 \times 10^{2}$ & $4.3 \times 10$ \\
\hline $\mathrm{C}$ & 2 & $5.0 \times 10^{1}$ & $4.2 \times 10^{2}$ & $1.4 \times 10$ \\
\hline 病 & 3 & $3.7 \times 10^{2}$ & $7.4 \times 10^{2}$ & $5.6 \times 10$ \\
\hline \multirow[t]{3}{*}{ 院 } & 4 & $5.8 \times 10^{4}$ & $5.8 \times 10^{2}$ & $4.8 \times 10$ \\
\hline & 5 & $1.0 \times 10^{3}$ & $1.9 \times 10^{2}$ & $3.4 \times 10$ \\
\hline & 平 均 & $1.5 \times 10^{4}$ & $5.0 \times 10^{2}$ & $3.9 \times 10$ \\
\hline
\end{tabular}

* : フードスタンプ寒天培地 $\left(10 \mathrm{~cm}^{2}\right)$ 上の細菌集落数より算出した。 
表 2. マットレスの MRSA による污染頻度

\begin{tabular}{|c|c|c|c|c|c|c|}
\hline 施 設 & 病 & 室 & 検査ベッド & SA & MRSA & MRSA 検出率\% \\
\hline A & - & 般 & 5 & 4 & 3 & 60 \\
\hline B & - & 般 & 4 & 4 & 1 & 25 \\
\hline $\mathrm{C}$ & - & 般 & 5 & 5 & 2 & 40 \\
\hline $\mathrm{D}$ & 婦 人 & 科 & 5 & 0 & 0 & 0 \\
\hline $\mathrm{E}$ & 老 & 人 & 6 & 3 & 3 & 50 \\
\hline $\mathrm{F}$ & 内科, & 外科 & 3 & 1 & 1 & 33 \\
\hline G & 内科, & 外科 & 2 & 2 & 2 & 100 \\
\hline $\mathrm{H}$ & 老 & 人 & 9 & 7 & 3 & 33 \\
\hline I & 老 & 人 & 6 & 9 & 4 & 67 \\
\hline $\mathrm{J}$ & 外 & 科 & 5 & 5 & 5 & 100 \\
\hline $\mathrm{K}$ & 老 & 人 & 2 & 2 & 2 & 100 \\
\hline 総 計 & & & 52 & 42 & 26 & 50 \\
\hline
\end{tabular}

$\mathrm{SA}:$ 黄色ブドウ球菌

MRSA：メチシリン耐性黄色ブドウ球菌

表 3. D 病院におけるベッド各部位*1 からの Staphylococcus aureus の検出

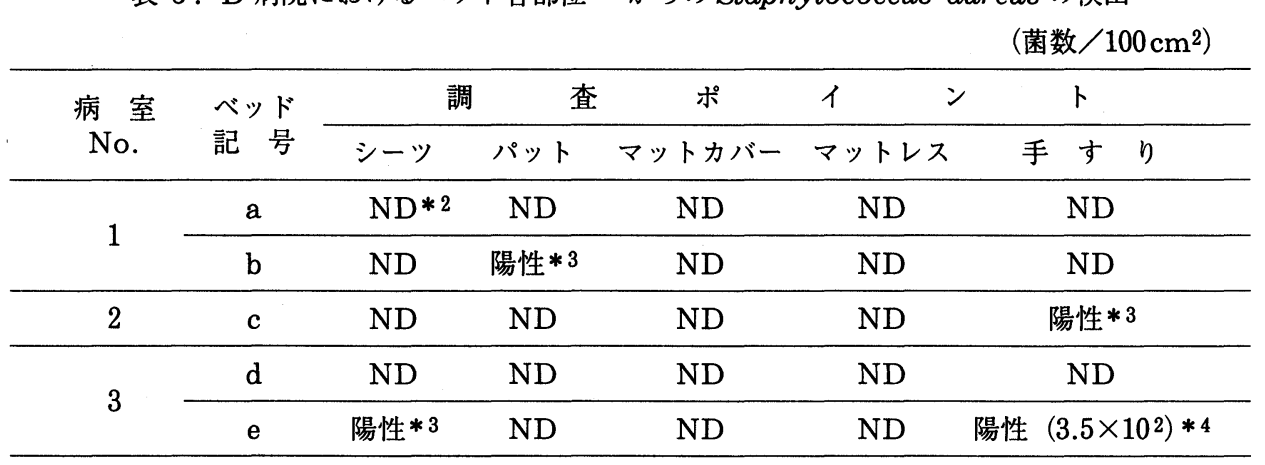

*1 ベッド用寝具の構成：通常の病院では, シーッの下は, パットあるいは布団であり, その下に マットレスがある。D 病院の場合は, マットレスはさらにマットカバー で包んである。

*2 ND: 不検出

*3 陽性 : 增菌培養でのみ検出。MRSA スクリーン培地で発育した。

*4 直接分離培養で検出 : S. aureus と同定された 3 株のうち, 2 株はMRSA スクリーン培地で 発育した。

き 3 カ所の平均值で表示し, 表 1 に示した。検出 された一般細菌数は, 拭き取り法では調べた約 50 $\%$ のマットレスより $\geqq 10^{5} \mathrm{CFU} / 100 \mathrm{~cm}^{2}$ の細菌数 が検出された。3病院のマットレスからの検出菌 数は, 拭き取り法がもっとも多く, 次いで掃除機 法, もっとも少ないのがスタンプ法であった。し たがって，以下の実験は拭き取り法で検体を採取
した。

\section{マットレスの MRSA 污染状況}

調査した 11 病院のマットレスからの黄色ブド ウ球菌と MRSA の検出状況を表 2 に示した。D 病院を除く残り10の病院のマットレスから 25〜 $100 \%$ の頻度で MRSA が検出された。表には示 していないが, 菌数は $\geqq 10^{5} \sim 10^{6} / 100 \mathrm{~cm}^{2}$ であっ 
た。唯一D 病院のマットレスからは，まったく 黄色ブドウ球菌は検出されなかった。そこで, D 病院のベッド関連部位から黄色ブドウ球菌の検出 を試みた。シーツ, パット, 手すりから検出率は 低いが, MRSAが検出された（表 3 )。患者につい ては調査出来なかったが, 患者の中には MRSA 保菌者がいて, 患者の手にも MRSA が付着して いると思われ, ベッドの手すりから $2 / 5$ の割合で MRSA が検出された。しかし, MRSAの分布は, シーツ又はパットまでで, パットより下のマット レスなどにはおよんでいなかった。

\section{病院内環境の MRSA の污染頻度}

病院内環境で MRSA がもっとも検出されやす い場所を知る目的で, 表 2 に記載したマットレス の検査結果より，50\%のマットレスから MRSA が検出された平均的な施設として $\mathrm{E}$ 病院の環境 調査を行った（表 4$)$ 。その結果, 病室をはじめ, 洗濯室, 浴室の脱衣室, トイレ, 污物一時保管室 （シーツ，オムツ等外部委託洗濯物の集荷場所） 等の床から高い確率で MRSA およびメチシリン
耐性卵黄反応陰性ブドウ球菌が検出された。メチ シリン耐性卵黄反応陽性ブドウ球菌 20 株のコア グラーゼ産生能を調べた結果, 19 菌株が 4 時間の 判定でコアグラーゼ陽性, 1 株も遅れて陽性を示 し，また卵黄反応陰性菌にはコアグラーゼ反応陽 性菌は認められなかった（結果未掲載）。以下本 論文では,メチシリン耐性卵黄反応陰性ブドウ球 菌をメチシリン耐性 CNS（MRCNS）と略称する。 黄色ブドウ球菌が検出された場所の大部分からは, MRSA も検出された。しかし，MRCNSの分布 は, MRSAの分布と一致しない場所もあったが, 黄色ブドウ球菌の分布とかなり一致していた。

次に $\mathrm{E}$ 病院内の場所と人のブドウ球菌の污染 状況を調査した。試料採取の場所（各 3 ケ所）は, ある階の 3 病室を任意に選出し, その階の患者の 使用するトイレ，浴室に限定した。また 3 人の患 者とその患者に接する機会の多い医療従事者（各 3 名）は，任意に選択した。人の試料は，手のひ らを拭き取って調製した。代表的な結果を表 $5 に$ 示した。医療従事者からの MRSAの検出菌数は

表 4.E 病院の MRSA の院内分布

（測定面積 : $100 \mathrm{~cm}^{2}$ )

\begin{tabular}{|c|c|c|c|c|c|c|c|c|}
\hline \multirow{2}{*}{\multicolumn{3}{|c|}{ 試 料 採 }} & \multirow{2}{*}{\multicolumn{2}{|c|}{ 取 場 所 }} & & 性 数 & ／ 検 & 数 \\
\hline & & & & & & 黄色ブドウ球菌 & MRCNS & MRSA \\
\hline \multirow[t]{3}{*}{ 病 } & & 室 & & 床 & & $7 / 18$ & $5 / 18$ & $6 / 18$ \\
\hline & & & i & - & ツ & $5 / 18$ & $1 / 18$ & $5 / 18$ \\
\hline & & & & ット & レス & $12 / 18$ & $10 / 18$ & $12 / 18$ \\
\hline \multirow[t]{2}{*}{ 洗 } & 濯 & 室 & & 床 & & $3 / 3$ & $2 / 3$ & $3 / 3$ \\
\hline & & & 汸 & 濯 & 機 & $0 / 3$ & $1 / 3$ & $0 / 3$ \\
\hline \multirow[t]{4}{*}{ 浴 } & & 室 & & 衣 & 室床 & $3 / 3$ & $3 / 3$ & $3 / 3$ \\
\hline & & & 肺 & 衣 & 棚 & $1 / 3$ & $0 / 3$ & $0 / 3$ \\
\hline & & & 棌 & 室 & 床 & $1 / 3$ & $0 / 3$ & $0 / 3$ \\
\hline & & & & & 槽 & $0 / 3$ & $1 / 3$ & $0 / 3$ \\
\hline ト & 1 & レ & & 床 & & $3 / 3$ & $3 / 3$ & $2 / 3$ \\
\hline \multirow[t]{2}{*}{ 污 } & 物 & 室 & & 床 & & $2 / 3$ & $2 / 3$ & $2 / 3$ \\
\hline & & & & 棚 & & $0 / 3$ & $0 / 3$ & $0 / 3$ \\
\hline \multicolumn{6}{|c|}{ 空調機給気口 } & $0 / 3$ & $0 / 3$ & $0 / 3$ \\
\hline \multicolumn{3}{|c|}{ ブラインド } & & & & $0 / 3$ & $0 / 3$ & $0 / 3$ \\
\hline \multicolumn{3}{|c|}{ 掃除用モップ } & & & & $1 / 1$ & $1 / 1$ & $1 / 1$ \\
\hline & リ ? & パ & & 者 & 用 & $2 / 5$ & $4 / 5$ & $2 / 5$ \\
\hline & & & & 来 & 用 & $1 / 2$ & $2 / 2$ & $0 / 2$ \\
\hline
\end{tabular}

MRCNS : メチシリン耐性卵黄反応陰性ブドウ球菌

MRSA：メチシリン耐性卵黄反応陽性黄色ブドウ球菌 
表 $5 . \mathrm{E}$ 病院の院内環境および患者と医療従事者のブドウ球菌污染状況

\begin{tabular}{|c|c|c|c|c|c|c|c|}
\hline & \multirow{2}{*}{\multicolumn{2}{|c|}{ 試 }} & \multirow{2}{*}{ 料 } & \multicolumn{3}{|c|}{ 数 $/ \mathrm{cm}^{2}$} & \multirow{2}{*}{$\begin{array}{l}\text { MRSA のコ } \\
\text { アグラーゼ型 }\end{array}$} \\
\hline & & & & 黄色ブドウ球菌*1 & MRCNS*2 & MRSA *3 & \\
\hline \multirow[t]{3}{*}{ 病 } & & 室 & 床 & 510 & 40 & 270 & II 型 \\
\hline & & & シ - ッ & $>600$ & 2 & $>600$ & II 型 \\
\hline & & & マットレス & $>600$ & 12 & 100 & II 型 \\
\hline 洗 & 濯 & 室 & 床 & $>600$ & $>600$ & $>600$ & II 型 \\
\hline 浴 & & 室 & 床 & 32 & $>600$ & 6 & II, VII 型 \\
\hline 卜 & 1 & レ & 床 & 36 & $>600$ & 30 & II, VII 型 \\
\hline \multicolumn{3}{|c|}{ 污物一時保管室 } & 床 & 52 & 100 & 46 & II, VII 型 \\
\hline 入 & 院 患 & 者 & & $>600$ & $>600$ & $>600$ & I, II, VII 型 \\
\hline 医 & & 師 & & $\leqq 1$ & $<1$ & $<1$ & \\
\hline 看 & 護 & 婦 & & $\leqq 1$ & $>600$ & 1 & II 型 \\
\hline 補 & 助 & 者 & & 2 & $>600$ & $<1$ & II, VII 型 \\
\hline
\end{tabular}

$* 1$ : 卵黄反応陽性黄色ブドウ球菌

*2 : メチシリン耐性卵黄反応侩性ブドウ球菌

*3 : メチシリン耐性卵黄反応陽性黄色ブドウ球菌

表 6. 患者, 医療従事者および健康者の MRSA 污染状況

(検出数 /検查数)

\begin{tabular}{|c|c|c|c|c|c|c|}
\hline & 試 & 料 & & 黄色ブドウ球菌 & MRCNS & MRSA \\
\hline \multirow[t]{3}{*}{ 患 } & 者 & 鼻 & 腔 & $15 / 20$ & NT & $15 / 20$ \\
\hline & & 咽 & 頭 & $11 / 20$ & NT & $11 / 20$ \\
\hline & & 手の & 平 & $7 / 20$ & $7 / 20$ & $8 / 20$ \\
\hline \multirow{3}{*}{\multicolumn{2}{|c|}{ 医療従事者 }} & 鼻 & 腔 & $7 / 16$ & $\mathrm{NT}$ & $3 / 16$ \\
\hline & & 咽 & 頭 & $7 / 16$ & $\mathrm{NT}$ & $3 / 16$ \\
\hline & & 手の & 平 & $1 / 16$ & $6 / 16$ & $0 / 16$ \\
\hline 健 & 康 & 鼻 & 腔 & $40 / 120$ & $0 / 120$ & $0 / 120$ \\
\hline
\end{tabular}

NT : 未検定

入院患者に比べ低いが，患者に接する機会の多い 看護婦および看護補助者からは MRCNS が患者 からとほほ同数検出された。調査した場所の床お よびシーツ，マットレスのすべてから, MRSA ま たはMRCNSが多数検出された。MRSAの代表 的集落（複数）について調べたコアグラーゼの型 は，看護婦と看護補助者から分離された MRSA のコアグラーゼ型は II 型と VII 型であり，患者か ら分離された MRSA のコアグラーゼ I, II, VII 型とほほ一致した。

健康人, 患者および医療従事者の MRSA 保有状 況

人の手のひらには, MRCNS や MRSA が非常
に多いことが分かったので， $\mathrm{E}$ 病院の別な入院患 者20名（無作為抽出）と医療従事者 16 名（希望 者）についてMRSAの保有状況を調べた。表 6 に検出結果を示した。鼻腔, 咽頭, 手のひらの各 部位では, 鼻腔の MRSA 陽性率がもっとも高かっ た。入院患者, 医療従事者, および健康人（大学 生）の間では, 入院患者の陽性率が高く, 病院環 境とは無関係な 120 名の健康人では, MRSA おょ びMRCNS の陽性率はともに0\%であった。

\section{考察}

今回調査した $90 \%$ の病院のマットレスは, MRSA で污染されていることが判明した。しか 
し, 患者用マットレスの MRSA の陽性率は, 病 院により $25 \%$ から $100 \%$ までと大きな違いがあ った。この陽性率の差は, マットレスの表面およ び内容物の材質, 使用目的, 使用期間, 洗濯と消 毒の有無などの違いによるものと考えられる。マ ットレスに関する情報が予想外にまったく入手 困難であったことより，どこにおもな原因がある のかは残念ながら不明であるが，マットレスの MRSA 污染率が意外に高いことが判った。しか し, D 病院では, MRSA が検出される可能性が高 いと予測されたある階の 5 病室を調べたが, シー ッやパットおよびベッドの手すりからわずかでは あるがMRSA が検出されているにもかかわらず, マットレスからはまったく MRSA が検出されな かった。マットレスから MRSAが検出されなかっ た要因として考えられることは, この病院は現在 すでにベッドセンターを設置し, マットレスの衛 生・品質管理を実施しており, また患者が変わる ごとに，あるいは定期的にマットレスを洗濯およ び消毒をし，またマットレスは袋状のマットカバー で包んでいるためと思われる。

現在寝具類の洗濯・消毒は, 一般にはシーツと 枕カバーのみで, パットやマットレスまで洗濯や 消毒をしている病院は今回調査した施設を含めほ とんどないと推測される。パットやマットレスの 洗濯, 消毒は, MRSA による污染とその拡散防止 のための手段として大いに有効であると考えられ る。トイレ, 浴場脱衣室, シーツ, オムツ等洗濯 物の污物一時保管室等の床からの MRSA 検出率 は高かったが, 空調機給気口, ブラインド等から はほとんど検出されなかった。したがって, 病院 の一般環境についてモニタリングを行う場合には, 床を中心に調べることにより，比較的効率良くそ の污染状況を把握出来るものと考えられる。しか し, $\mathrm{E}$ 病院の場合, 患者から MRSA が検出され ているにもかかわらず室内の床 3 地点の拭き取り で MRSA は検出されず，一方では床清掃後のモッ プから MRSA が検出された病室もあった。この 病室は, 入院患者 8 名中 7 名が歩行困難であった。 また, 別室の患者 5 名のスリッパを検査したとこ ろ, 自主独立で歩行可能な 2 名の患者のスリッパ から MRSA が検出された。このことは MRSA 保菌者の歩行範囲（病室の床, トイレ, 浴室など） にMRSA が検出されることを示していると考え
られる。したがってスリッパや床掃除後のモップ の消毒が MRSA の二次污染防止のために必要で あろう。

洗濯室の床と病室から回収したオムッやシーツ 等外部委託用洗濯物を入れた大型布製袋を一時 保管する場所，特に袋の接している床部分には， MRSA が濃厚に存在している。このことは, 院 内での污物の回収, 運搬, 保管等の方法および洗 濯室（洗濯業者を含めて）への污物の搬出運搬と その洗濯の方法等を慎重に検討する必要を示唆す る。

今回使用した MRSA 分離培地は, MRSA の選 択培地としてだけではなく15)，MRCNS を効率よ く分離定量出来ることが判った。MRCNS と黄色 ブドウ球菌間でのメチシリン耐性遺伝子の移行は まだ証明されていないが6)，免疫力の低下してい る患者では MRSA はもちろん MRCNS での重篤 な感染も多いものと考えられるので, MRCNS 検 出定量の意義は大きいと考えられる。

本調査結果から, MRSA の院内感染防止対策 に関するモニタリング法として，次のような提言 をしたい。

1. モニタリングする場所は, 病室の床とマット レスを重点的に行うべきである。

2. 検査試料は, 床やマットレス $\left(100 \mathrm{~cm}^{2}\right)$ を 強固な大形ピンセットを用い強く拭く拭き取り 法で採取する。

3. MRSA 分離培地等適当な培地を使用して, MRSA と MRCNSを同時にかつ定量的に把握 する。

4. 寝具類は, シーッのみならずマットレスをも 含め, 定期的に洗濯と消毒をする。

5. 洗濯物を含め病室からの污物は, MRSA を 飛散拡散させないよう, 取り扱いには充分に注 意する。

6. 手術前後の患者や免疫機能の低下している患 者は勿論, 入院時の患者についても鼻前庭から MRSA の検査を行い, 院内での污染の拡散を 最小限に止めるよう防止対策をたてることが必 要である。

謝 辞: この調査研究の一部は, 伊藤忠商事株式 会社からの研究助成金によってなされた。 


\section{文献}

1）相原雅典，酒井美智子，岩崎瑞穂，島川宏一，小崎 節子, 窪 真理, 上木正成，高橋 浩, 赤石強司, 山本育由 (1990): Methicillin 耐性黄色ブドウ球 菌による未熟児室内感染とその対策一ポピドンヨー ド液清拭の有用性について一, 感染症学雑誌，64, 479-485.

2) American Hospital Association Committee on Infections Within Hospitals (1974) : Statement on microbiologic sampling in the hospital. Hospitals, 48, 125-126.

3) Eickhoff, T.C. (1970) : Microbiologic sampling. Hospitals, 44, 86-87.

4）深山牧子，稲松孝思（1988）:老年者における MRSA 感染の現状. 臨床と微生物, 15, 174-177.

5) Haley, R.W. (1980): The emergence of infection surveillance and control programs in U.S. hospitals; an assessment. Am. J. Epidemiol, 111, 574-591.

6）平松啓一（1990）:メチシリン耐性黄色ブドウ球菌 （MRSA）の耐性のしくみとその対策. 第63 回日 本細菌学会関東支部総会講演抄録. 35-36.

7）川名林治（1986）：院内感染と対策. 臨床と微生物, 13, 295-304.

8）松尾収二, 相原雅典, 高橋 浩 (1991)：便よりメ チシリン耐性黄色ブドウ球菌が検出された 34 患者 の臨床的および病理学的検討. 感染症学雑誌, 65, 1394-1402.

9）迎寛, 岩本雅典, 高瀬登美子, 森理比古, 石 野 徹, 道津安正, 河野 茂, 山口恵三, 広田正 毅，原 耕平 (1990)：当院の過去 4 年間における Methicillin-resistant Staphylococcus aureus （MRSA）の分離状況一院内感染としての MRSA. 感染症学雑誌, 64, 1275-1286.

10）永井 勲, 門田 稔, 武智 誠, 熊本良悟, 中野静
子, 大ケ瀬浩史, 谷岡博昭 (1989)：手術部内環境 の清潔状態の現状とその推移. 防菌防徽，17，6975.

11）中丸勝人, 宮崎久義, 牛島一男, 愑口昭子, 伊藤裕 輔, 増田 明, 久世照五 (1981) : 手術部細菌検查 と清潔管理一富山医薬大手術部発足後 1 年余の経 過から一. 医器学, 51, 582-587.

12）西順一郎, 茂幾明彦, 吉永正夫, 松山佳織, 相星壮 吾, 宮田晃一郎, 宮之原晃, 尾辻省悟 (1991)：当 院における MRSA 院内感染の様相. 第 1 報 : コア グラーゼ型別による検討. 感染症学雑誌, 65, 1121 -1129 .

13) Parker, M.T. (1984): Staphylococcus and Micrococcus; the anaerobic gram-positive cocci. 218-245, In Parker, M.T. (ed.), Topley and Wilson's Principles of bacteriology, virology and immunity. 7th Edition. Vol. 2, Edward Arnold, London.

14）四方田幸恵, 高橋綾子, 角田佐穂里, 小林 功, 大久保豊司, 井上松久 (1991) : 群馬大学医学部付 属病院におけるメチシリン耐性黄色ブドウ球菌 (MRSA) の分離状況一第 1 報一. Chemotherapy， $39,813-821$.

15）田口文章, 滝 龍雄, 奥田舜治, 菊野理津子 (1992)： 新しい多剤耐性（メチシリン耐性）ブドウ球菌選 択培地の有効性の検討. 日細菌誌 47, 759-765.

16）高橋泰子, 小林寛伊，釷宮豊城，林キイ子, 都築正 和 (1985) : 各種病院手術室における空気清净度の 測定. 防菌防微, 13, 161-168.

17）渡辺正治, 久保勢津子, 石山尚子, 畠山靖子, 斎藤 知子, 高橋公毅, 菅野治重, 陳 瑞明 (1987): 千 葉大学付属病院における Methicillin-resistant Staphylococcus aureus (MRSA) の分離状況最近 5 年間の観察一. Chemotherapy, 35, 467475 . 


\title{
Proposal for the Nosocomial Infection Control of Methicillin- Resistant Staphylococcus aureus (MRSA)
}

\author{
F. TAGUCHI ${ }^{1}$, T. SAITO-TAKI ${ }^{1}$, S. OKUDA ${ }^{2}$, M. AOKI ${ }^{2}$, \\ T. MATSUZAKI ${ }^{2}$, M. TOMIOKA ${ }^{2}$, R. KIKUNO ${ }^{2}$ and S.M. LEE ${ }^{1}$ \\ 1 Department of Microbiology, Kitasato University School of Hygienic Sciences \\ 2 Kitasato Research Center of Environmental Science \\ 1-15-1, Kitasato, Sagamihara, Kanagawa, 228 Japan
}

To determine the prevalence of methicillin-resistant Staphylococcus aureus (MRSA) in hospital environments, quantitative isolation of MRSA from environmental and human specimens was performed.

It was found that as many as $6 \times 10^{4}$ colony forming units (CFU) $/ 100 \mathrm{~cm}^{2}$ of MRSA and also methicillin-resistant coagulase-negative Staphylococcus (MRCNS) were isolated from 1) 25 $\sim 100 \%$ of the bed-mattresses tested in 10 out of 11 (90\%) hospitals, and also 2) bed sheets for patients, floors of patient wards, laundry, bath-room, toilet and laundry storage-room. And seven and eight palms of 20 patients were contaminated with MRCNS and MRSA, respectively, and MRCNS contamination was revealed in six of medical staffs. These results indicate that hospital environments, especially the mattresses and hospital floors are highly contaminated with MRCNS and MRSA, and sanitation and cleanliness of mattresses and floors are necessary to prevent the dissamination of both MRCNS and MRSA in hospital. 